Journal of

Education and Practice (JEP)

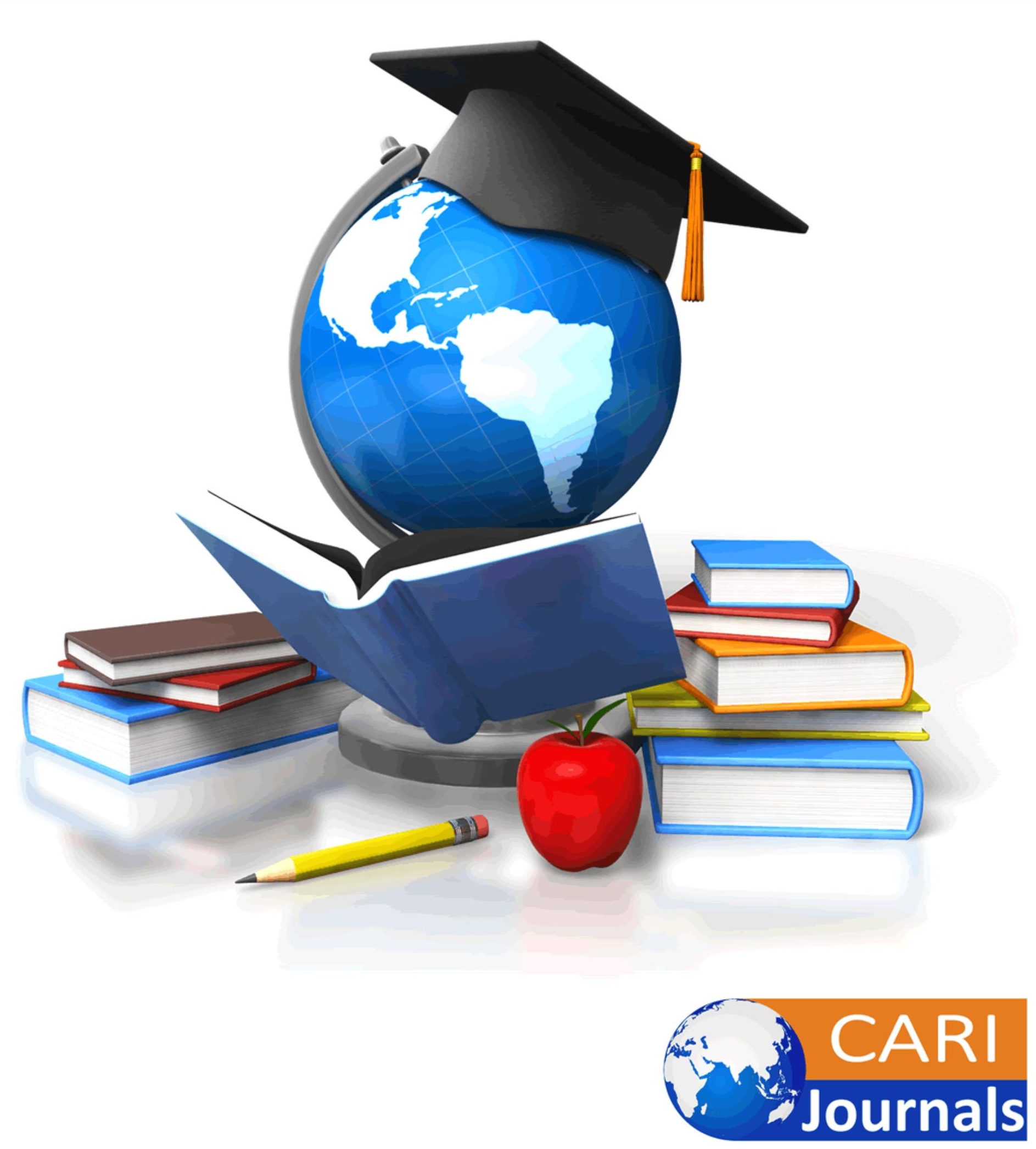




\title{
Self-assessment of Information and Communication Technology (ICT) Competence Needs Among Student-Teachers Using UNESCO ICT-CFT in Colleges of Education in North Central, Nigeria
}

\author{
1*Anaza, Abdulmumuni Onuyi \\ ${ }^{1}$ Curriculum and Instruction, Federal College of Education, Okene, Kogi State, Nigeria \\ *Corresponding Author's Email: anazao74@gmail.com
}

\begin{abstract}
Purpose: The objective for the study was using the fourth level of UNESCO ICT-CFT on the technology literacy approach to determine student-teachers' self-assessment of ICT competency needs in colleges of education.
\end{abstract}

Methodology: The study adopted the descriptive research of cross-sectional survey type.

Three research questions and two hypotheses were drawn. A total of 1,211 student-teachers were randomly selected from 11 colleges of education in North-central, Nigeria. Data were collected through administration of validated questionnaire adapted from UNESCO ICT-CFT. Mean was used to answer the research questions 1-3 while t-test and Kruskal Wallis were used to test hypotheses one and two respectively.

Findings: The result revealed that based on the fourth level of the Technology Literacy approaches of UNESCO ICT-CFT, student-teachers in the colleges of education have high ICT competence needs; there was a significant difference among male and female student-teachers ICT competence needs in ICT integration; also, there was significant differences in area of specialization of student-teachers ICT competence needs in ICT integration.

Unique contribution to theory, practice and policy: The study therefore recommended that government in collaboration with private sector should provide student-teachers with the required ICT needs to be at par with their counterpart from other parts of the world; government and authorities of colleges of education should take into consideration female student-teachers while planning to integrate ICT in colleges of education and in procurement of ICT facilities; and student-teachers area of specialization should be taken into consideration during the purchase of ICT facilities for student-teachers use in colleges of education.

Key Words: Self-assessment, ICT, ICT Competence Needs, UNESCO ICT-CFT, Colleges of education.

\section{INTRODUCTION}

In educational institutions in developed and developing countries of the world, today's classroom teachers must be prepared to provide technology-supported learning opportunities for their students. Schools and classrooms in elementary, secondary, and tertiary institutions must have teachers who are equipped with information and communication technology (ICT) resources and skills, and who can effectively teach the content in subject matter while incorporating technology concepts and skills. There is hardly any doubt that traditional practices can no longer provide prospective teachers with all the required skills for teaching in the classroom. ICT offer schools opportunities to improve student learning outcomes. When 
Journal of Education and Practice

ISSN 2520-467X (Online)

Vol. 5, Issue No.1, pp 17 - 35, 2021

WWW.carijournals.org

ICT are used in classrooms, it provides students with opportunities to develop the skills and attributes that prepare them for an increasingly ICT- mediated, globalized world. Lim (2012) stated that these skills and attributes include but not limited to, accessing information, communication, developing knowledge, presentation of ideas, Problem-solving, collaboration and learning how to learn. In these ICT-mediated classrooms, the role of teacher is pivoted in the design and implementation of effective teaching and learning activities that engage student in the development of skills and attributes (Lim \& Chai, 2008). Therefore, teachers have to be equipped and upgraded with the necessary ICT knowledge and skills in education in the preservice teacher education experiences.

The effective integration of ICT in the schools and classrooms can transform pedagogy and empower students (UNESCO, 2018). In this context, it is essential that teachers have the competencies to integrate ICT in their professional practice to ensure the equity and quality of learning. Teachers also need to be able to harness ICT to guide learners in developing Knowledge Society skills such as critical and innovative thinking, complex problem solving, the ability to collaborate, and socio-emotional skills. Teacher training and continued on-going, relevant professional development for teachers are essential if benefits from investments in ICTs are to be realized. Training and on-going support must enable teachers to develop the necessary ICT competencies so they can, in turn, ensure their students develop the relevant skills, including digital competencies for life and work.

ICT are the varied collection of technological gear and resources that are employed in communication (Sukanta, 2012). Sukanta (2012) further viewed ICT as resources used to generate, distribute, collect and administer information. Shukere (2008) added that ICT includes hardware, software and media for collection, storage, processing, transmission, presentation of information and related services. In the field of education, ICT can be seen as a collection of technologies for gathering, accessing and dissemination of data for enhanced learning (Miller \& Akume, 2009). The various ICT facilities that could be used in education include radio, television, computers, fax machine, CD Rom. Internet, electronic notice board, slides and digital multimedia, video machine, photocopying machine, scanner and many others (Bandele, 2006). The utilisation of ICT for teaching and learning has made education easier through the application of electronic media, the internet and many others and teacher must be trained on how to use ICT during their training.

Colleges of education is one of the tertiary institutions in Nigeria saddled with the responsibility of training middle class teacher for the lower and upper basis schools. Colleges of education are aimed at producing manpower to cater for the lower and upper basic schools (Olumorin, 2008). Olumorin, (2008) further noted that Colleges of Education are expected to contribute to national development by intensifying and diversifying its programmes for the development of manpower needs of the nation and making professional course contents to reflect our national regiments. Thus, the knowledge of ICT for the purpose of teaching and learning cannot be underestimated. To be able to cope, or otherwise, with these functions, there is the need for student-teachers to be competent with ICT usage during their training.

UNESCO ICT-CFT pointed out that teachers' competence must have basic hardware and hardware operations as well as productivity application software, a web browser communication, software presentation, software and management applications. Titilayo (2010) study concurs with the fact that the number of ICT teachers who have basic technological skill in the use of ICT is low. In comparison, Hooker, Mwiyeri and Verma (2011) reported that ICT technology domain such as the ability to use ICT open ended software packages appropriate to 
Journal of Education and Practice

ISSN 2520-467X (Online)

Vol. 5, Issue No.1, pp 17 - 35, 2021

WWW.carijournals.org

subject matter areas, the ability to use an authorizing environment or tools to design offline and/or web resources is low.

In response, UNESCO has developed the ICT Competency Framework for Teachers (ICT CFT) as a tool to guide pre- and in-service teacher training on the use of ICTs across the education system. The ICT CFT is intended to be adapted to support national and institutional goals by providing an up-to-date framework for policy development and capacity building in this dynamic area.

Therefore, in assessing the student-teachers ICT competence needs, consideration has to be given not only to the extent of competence in the use of ICT in personal activities but the competence should reflect in all their endeavours. According to Yusuf (2005), Nigerian teachers are not competent in basic computer operation and the use of generic software, although they have positive attitude towards the use of the computer. This finding revealed the low levels of ICT penetration in the Nigerian school system. Yusuf further noted that teachers in schools do not use ICT in teaching students because they lack the competence to use ICT to facilities teaching-learning processes. This implied that school leavers who are prospective student-teachers would have no skill of ICT use in their respective classes. Therefore, in assessing ICT competence needs of student-teachers in ICT, consideration has to be given to student-teachers' gender and area of specialization.

In sub-Sahara Africa, gender issues exist in education where the girl-child is deprived of any opportunity to gain ICT-related knowledge and skills (Yusuf \& Balogun, 2012). They observed further that African women have the lowest enrolment rates in the World in science and technology at all levels. This is why gender is considered an important variable that may influence self-assessment of ICT competence needs among student-teacher. Gender division appear frequently in technology discussions and as such is difficult to avoid the stereotypical notion that female is less-savvy in ICT related issues. Markausaite (2006) investigated gender differences in a self-reported ICT experience and ICT literacy among first year graduate trainee teachers and discovered a significant difference between male and female in technical ICT capabilities, situational and longitudinal sustainability in favour of the male.

Another factor that may influence self-assessment of ICT competence needs among studentteachers in colleges of education included in this study was student-teachers' area of specialization. Student-teachers' area of specialization is the various branches that exist in the body of knowledge within their learning environment (Olumorin, 2008). Student-teachers' area of specialization is the school they fall into in the college of education based on the course they offered. As stated in the National Commission for College of Education, NCCE (2012) minimum standard, there are five schools in the colleges of education system namely School of Education, Sciences, Vocation, Arts and Social Sciences and Languages. The kind of training received by these student-teachers in their respective areas of specialization may influence their opinion on their student-teachers should be equipped with digital literacy competencies to exploit the information resources that the electronic age provides at their fingertips (Nash, 2009). Nash (2009) further stated that there is an urgent need for ICT competence to be given to fresh student-teachers so as to obtain successful learning outcomes from the use of irrespective of areas of specialization.

There have been three ICT CFT versions: 2008, 2011 and 2018. Each version has reflected the prevailing thinking on the relationship between technology and education, with suggestions on how to achieve competencies using popular technologies of the time. From the outset, it was 
Journal of Education and Practice

ISSN 2520-467X (Online)

Vol. 5, Issue No.1, pp 17 - 35, 2021

WWW.carijournals.org

envisaged that the ICT CFT would be dynamic and revisited regularly to ensure relevance. Therefore, ICT competence needs of student-teachers was assessed the fourth level of the UNESCO ICT-CFT based on the literacy approach. Survey questionnaire adapted from the UNESCO ICT-CFT was used to collect data while the statistical tool for this study was mean, $\mathrm{t}$ test and Kruskal Wallis.

The UNESCO's Framework stressed that it was not enough for teachers to have ICT competencies and teach them to their students, but they need to be able to help the students become creative learners through the use of ICT (UNESCO, 2018). The framework, therefore, addresses some of the following parameters: Understanding ICT in education, curriculum and assessment, Pedagogy, ICT, Organization and Teacher professional learning. UNESCO (2018) further stated that the framework is organized in three significant approaches to teaching. The first approach is Technology Literacy which enables learners to use ICT efficiently. Knowledge deepening, which is the second approach, enables students to acquire in-depth knowledge of their study and apply it to solving complex, real world problems. The third approach is knowledge creation that enables students, citizens and the labour force to utilize the new knowledge acquired for more harmonious, fulfilling and prosperous societies as see in fig. 1

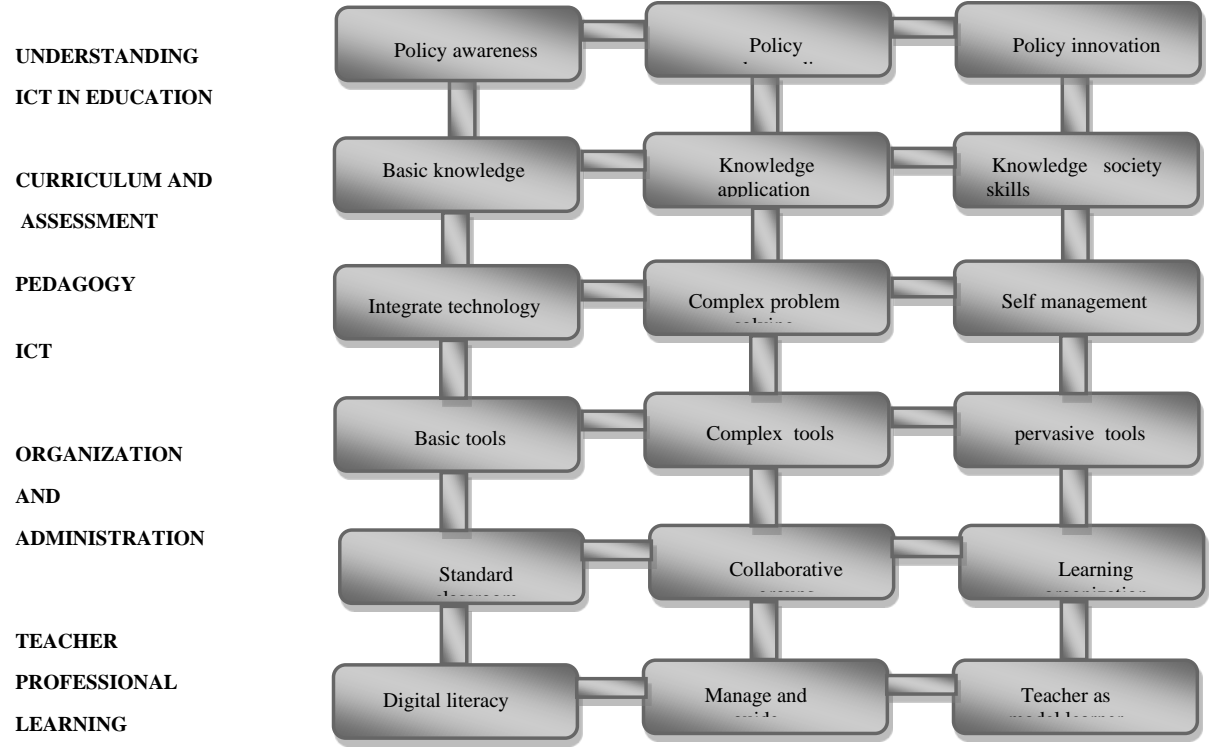

Figure 1: The UNESCO ICT Competency Framework for Teachers

\section{Statement of the Problem}

ICT is having a revolutionary impact on educational methodology globally and the Nigerian teacher is not an exception (Tinio, 2004; Ololube, 2006). There is no doubt that to live, learn and work in an increasingly complex, ICT-driven society, teachers and student must use technology (UNESCO, 2008; UNESCO, 2011, UNESCO, 2018). UNESCO (2018) ascertained that within a sound educational setting, technology can enable teachers and students to be more comfortable during teaching and learning process. It was concluded in the same document that these are only possible in a learning environment where student-teachers are provided with the right ICT tools and exhibit adequate competence in the application of these ICT for teaching and learning. 
Journal of Education and Practice

ISSN 2520-467X (Online)

Vol. 5, Issue No.1, pp 17 - 35, 2021

WWW.carijournals.org

Student-teachers have to learn how to use ICT in the classroom situations since it has provided new possibilities for the teaching profession. However, Swamy (2010) stated that most of the teacher education institutions are facing difficulties like shortage of lecturers that are competent in the use of ICT in teaching, weak curricula, lack of ICT equipment and a host of others. Instances where ICT are available in the schools, they hardly meet the needs of the studentteachers because ICT facilities were purchased without any competence needs assessment (Swamy, 2010).

The factors affecting the extent to which student-teachers attain necessary knowledge in teacher education programmes have received little attention by researchers and policy makers (Albirini, 2006; Tezci, 2009). Usun (2003) indicated that comprehensive research is needed in education. According to Usun (2003), it is also important to identify factors that affect studentteachers' use of ICT and these includes their ICT competency of student-teachers to utilized ICT to their full potentials within the education system is imperative. However, one has to establish the student-teachers ICT competency needs. Oyediran and Odunsami (2004) revealed that capacity development of educators and ICT facilities that can integrate ICT use and competence have been taken for granted. Thus, this called for self-assessment of ICT competence needs of student-teachers in colleges of education in North central, Nigeria.

\section{Objectives of the Study}

This study assessed self-assessment of ICT competence needs among student-teachers using UNESCO ICT-CFT in colleges of education in North central, Nigeria. Specifically, the study based on the fourth level of UNESCO ICT on the technology literacy approach, determined.

1. Student-teachers' self-assessment of ICT competence needs in colleges of education

2. Student-teachers self-assessment of ICT competence needs in colleges of education as influenced by gender

3. Student-teachers self-assessment of ICT competence needs in colleges of education as influenced by area of specialization.

\section{Research Questions}

Answers were sought to the following questions:

1. What are the students-teachers self-assessment of ICT competence needs in the fourth level of UNESCO ICT-CFT on the technology literacy approach in colleges of education?

\section{Research hypotheses}

The following hypotheses were formulated and tested at 0.05 level of significance:

$\mathrm{H}_{\mathrm{O} 1}$ : There is no significant difference between self-assessment of ICT competence needs by male and female student-teachers in the fourth level of UNESCO ICT-CFT on the technology literacy approach in colleges of education.

$\mathrm{H}_{\mathrm{O} 2}$ : There are no significant differences in the area of specialization of student-teachers of self-assessment of ICT competence needs in the fourth level of UNESCO ICT-CFT on the technology literacy approach in colleges of education. 
Journal of Education and Practice

ISSN 2520-467X (Online)

Vol. 5, Issue No.1, pp 17 - 35, 2021

WWW.carijournals.org

\section{LITERTURE REVIEW}

\section{Empirical Review}

It is no longer a question whether or not technology should be used in the classroom. The emphasis is ensuring that teachers use technology effectively to create new opportunities for students to learn and raise their achievement. The use of technology in the classroom requires teachers to be knowledgeable and competent in ICTs and to integrate them into the curriculum, align them with student learning goals, and use them to engage learners in a quest for meaningful academic development. Competency as defined by UNESCO (2005) is a set of attributes that encompasses knowledge, skills and expertise for enabling an individual to effectively perform the activities and function to the standards required an occupation. This is the competency that teachers should possess to enable them deliver and transfer requisite knowledge and skill. Competence needs to be subsumed in teacher practices (Tayo \& Adedayo, 2013). Society for Information Technology and Teacher Education (SITE) (2002) noted an increasing demand for teacher education programmes to graduate teachers that would be confident and competent in using ICT for their personal and professional lives. Teacher education programmes to prepare student-teachers that will fit into classroom of tomorrow need to develop programmes that instill ICTs into the entire programme using authentic and pedagogically appropriate approaches to achieve desired objectives. That is, student-teachers should learn about, learn with, and learn to incorporate ICT into their learning and eventually teaching.

ICT integration and utilization in the schools represent a new professional role as being a sign of the changes in teaching profession (Yildirim, Kynigos, Potolea, Dumont \& Aufenanger, 2003). This role changing embraces various competencies related to technology and their integration into real-life school environments. These technology competencies relating with education define what a teacher has to know and has to do to provide successful education (Yildirim, Kynigos, Potolea, Dumont \& Aufenanger, 2003). Perhaps one of the greatest challenges facing teacher education today concerns the preparation of good quality teachers capable of using ICT effectively. Unless and until they are trained and are competent in the use of it, no qualitative changes in teaching should be expected.

Johnson (2012) noted that student-teachers should be able to exploit the potentials of ICT to meet his or her teaching goals. Student-teachers in the Colleges of Education should be technologically competent, both during their training and in their future employment so as to make sound judgments about when, how to use it, and become confident and competent users of ICT in the teaching learning process (Johnson, 2012). Khan (2001) found out that the level of competency of lecturers and student-teachers were enhanced using ICT, This gave them the capability to deliver a more enhanced graphics-oriented presentation of lectures. He also found out that if institutions and student-teachers/lecturers are provided more time to develop quality instruction, teachers are more liable to efficiently develop and prepare presentations and monitor student's progress more efficiently.

Therefore, in assessing the competence of student-teachers in ICT, consideration has to be given not only to the extent of competence in the use of ICT in personal activities but the competence should reflect in all their endeavours. According to Yusuf (2005), Nigerian secondary school teachers are not competent in basic computer operation and the use of generic software, although they have positive attitude towards the use of the computer. This finding revealed the low levels of ICT penetration in the Nigerian school system. Yusuf further noted 
Journal of Education and Practice

ISSN 2520-467X (Online)

Vol. 5, Issue No.1, pp 17 - 35, 2021

WWW.carijournals.org

that teachers in secondary schools do not use ICT in teaching students because they lack the competence to use ICT to facilities teaching - learning processes. This implied that secondary school leavers who are prospective student-teachers would have no skill of ICT use in their respective classes.

In Nigeria, Omoniyi and Quadri (2013) revealed that prerequisite ICT competences among school teachers were not found. The study also revealed that teacher' competences were not influenced by their teaching experience and academic qualifications. Archibong, Ogdiji and Anijaobi-Idem (2010) revealed similar results among university academics in universities in Cross River State Nigeria. Similarly, Ojedokun and Owolabi (2003) reported that their respondents used the internet for research than they did for teaching purposes. This suggests an urgent need for ICT training to be offered to fresh student-teachers to obtain successful learning outcomes from the use of ICT and to satisfy the needs of the future employer.

Empirical works on student-teachers' competence in the use of ICT provided an in-depth review to point out the ICT competence needs. Research has revealed that student-teachers need to acquire digital age literacy and learn how to use technology as a tool for learning, solve problem, share knowledge, create original work and so on. Low level of competence was however reported by Idowu, Adagunodo and Idowu (2004) Yusuf (2005). Though Atan, Azil, Rahman and Idrus (2002) pointed out that user exhibited greater competences with frequent computer and student-teachers' competence which relates directly to confidence of the studentteachers. Therefore, this study sought to out student-teachers ICT competence needs in colleges of education.

This study therefore, determined self-assessment of student-teachers' ICT Competence Needs based on the fourth level of UNESCO ICT-CFT, at the Technology Literacy approach. The UNESCO ICT-CFT is a framework that outlines the competencies that teachers need to integrate ICT into their professional practice hence the basis for using it in this study. The items in the questionnaire were based on the fourth levels of UNESCO ICT-CFT on the Technology literacy approach.

\section{METHODOLOGY}

\section{Research Design}

This study adopted the descriptive research of the cross-sectional survey type. This is an approach that seeks to explain phenomena by using predetermined instruments to collect data for analysis through some statistical techniques using a certain population to represent the entire population. The approach allows the research to measure the diverse views, perspectives and opinions of the ICT competency needs

\section{Study Area}

The population for this study was student-teachers in colleges of education in Nigeria while the target population was student-teachers in colleges of education in North central states in Nigeria. The states in the North central include Kwara, Kogi, Benue, Plateau, Nasarawa, Niger state and the federal capital territory. There are 24 colleges of education in the North Central, four are owned by the Federal Government, 11 by states Government and 9 by private organizations. A total of 11 colleges of education across the 6 states and Abuja will be involved in the study. 
Journal of Education and Practice

ISSN 2520-467X (Online)

Vol. 5, Issue No.1, pp 17 - 35, 2021

WWW.carijournals.org

\section{Sample and Sampling Technique}

The general sample size was draw from student-teachers in the 23 colleges of education consisting of four federal colleges of education, 10 states colleges of education and 9 private Colleges of Education. The random sampling technique was used to select 11 colleges of education from the zone since colleges of education were established by the same Decree and operate on the same minimum standard. Private colleges of education were left out in this study because some of them did not meet the minimum standard.

The sample size was drawn from the total number of student-teachers in their final year of study (NCE 3) since they had gone through most of the theoretical courses and completed their teaching practice exercises as well. Random sampling technique was also used to select the 1,211 student-teachers involved in the study out of the target population of 35,329 . The sample selection of student-teachers was based on the Israel model.

\section{Research Instrument}

The research instruments used in this study was a questionnaire adopted from UNESCO ICTCFT (UNESCO, 2011) titled "Student-teachers ICT competency Needs in Colleges of Education" (STICTTNCOE). The questionnaire was based on the fourth level of UNESCO ICT-CFT (UNESCO, 2011) at the Technology Literacy approach.

The questionnaire had six major sections labelled Sections A, B, C, D, E and F. Section A dealt with the student-teachers bio-data containing information on the respondents' gender, and area of specialization. Section B of the instrument contained 23 items related to student-teachers ICT competency needs on hardware with response modes of: highly needed, fairly needed and not needed. Section C contains 12 items ICT competency needs on software with response modes as in B. Section D contains 13 items on ICT competency needs on computer operation with response mode as in B. Section E is made up of 6 items on ICT competency needs on the use of other ICT with computer with the same response modes as in B. Section F contains 16 items on ICT competency needs on the use of the internet with response modes as in B.

The questionnaire for the study were given to expert in Information Technology at the STEPB project of the Federal College of Education, Okene and two lecturers in the department of Educational Technology, University of Ilorin, Ilorin to establish the face and content validity. Their advice, suggestion, comments and corrections led to the modification of the questionnaire before the production of the final questionnaire. The items used in the instrument were adjudged to be relevant to what was being measured thereby ensuring both the content and face validity of the instrument.

A pilot study was conducted on twenty student-teachers at the Federal College of Education, Zaria while the Cranach Abuja was adopted to verify the reliability of the questionnaires. The items on the questionnaire for the student-teachers were reliable at 0.86 .

The Researchers and his research assistants sought permission from the Provosts or their representatives of the sampled schools involved in the research. The researchers and his assistants visited the sampled colleges with copies of the questionnaire for administration. Out of a total of 1,360 copies of the questionnaire distributed, 1,211 copies were returned which represents $89.04 \%$ return rate. The 1,211 copies of the questionnaire returned were used for the data analysis in this study.

In assessing the self-assessment of ICT needs among student-teachers in colleges of education using questionnaire as in instrument, mean was used to analyze the data collected. The questionnaires were coded and analyzed using Statistical Science Package for Social sciences (SPSS) version 23.0 for windows. 
Journal of Education and Practice

ISSN 2520-467X (Online)

Vol. 5, Issue No.1, pp 17 - 35, 2021

www.carijournals.org

\section{FINDINGS AND PRESNTATION}

\section{Demographic Findings}

The demographic representations of student-teachers were presented table 1:

Table 1: Percentage Distribution of Respondents (Student-teachers) by Gender

\begin{tabular}{lcc}
\hline Gender & Frequency & Percentage \\
\hline Male & 491 & 40.5 \\
Female & 720 & 59.5 \\
Total & 1211 & 100 \\
\hline
\end{tabular}

Table 1 reveals that $491(40.5 \%)$ of the respondents were male while $720(59.5 \%)$ of the respondents were female. This implies that female participated more than the male in the study.

Table 2: Percentage Distribution of Respondents (Student-teachers) by Schools in the Colleges

\begin{tabular}{lcc}
\hline Schools & Frequency & Percentage \\
\hline Education & 484 & 39.97 \\
Sciences & 324 & 26.76 \\
Vocation & 133 & 10.98 \\
Languages & 126 & 10.40 \\
Art and Social Sciences & 144 & 11.89 \\
Total & 1211 & 100.00 \\
\hline
\end{tabular}

Table 2 reveals that $484(39.97 \%)$ of the respondents were from the school of education, 324 $(26.76 \%)$ of the respondents were from sciences, $133(10.98 \%)$ of the respondents are from the school of vocation, $126(10.40 \%)$ of the respondents were from school of Languages and 144 $(11.89 \%)$ were from the school of Art and Social Sciences. This implies that student-teachers from the school of education and sciences participated more in the study than student-teachers from the other three schools.

\section{Analysis of Research Question}

\section{Research Question One}

What are the students-teachers self-assessment of ICT competency needs in the fourth level of UNESCO ICT-CFT on the technology literacy approach in colleges of education?

Table 3: Student-teachers assessment of ICT Competence Needs in ICT Integration (Hardware)

\begin{tabular}{llc}
\hline S/N & Items & Mean \\
\hline 1. & Desktop Computer & 2.85 \\
2. & Laptop Computers & 2.83 \\
3. & Palmtop Computers & 2.58 \\
4. & Wireless Internet & 2.70 \\
5. & Cable Internet & 2.52 \\
6. & Digital camera & 2.42 \\
7. & Scanner & 2.54 \\
8. & Video equipment & 2.33 \\
9. & Projector & 2.64 \\
10. & Television set & 2.32 \\
\hline
\end{tabular}


Journal of Education and Practice

ISSN 2520-467X (Online)

Vol. 5, Issue No.1, pp 17 - 35, 2021

www.carijournals.org

\begin{tabular}{llr}
\hline 11. & Interactive boards & 2.47 \\
12. & Computer printer & 2.69 \\
13. & Photocopiers & 2.59 \\
14. & Virtual library & 2.52 \\
15. & Electronic bulletin board & 2.48 \\
16. & Electronic notice board & 2.32 \\
17. & Radio & 2.27 \\
18. & Tape recorder & 2.32 \\
19 & CD player & 2.26 \\
20 & Digital video disc player (DVD) & 2.23 \\
21 & Slide projectors & 2.35 \\
22 & Smart phones & 2.26 \\
23 & CD/DVD writers & 2.38 \\
& Grand Mean & $\mathbf{2 . 4 7}$
\end{tabular}

Table 3 revealed a grand mean of 2.47 for student-teachers of ICT competence needs in ICT integration (hardware) based on the Technology Literacy approach of UNESCO ICT-CFT. This reveals that student-teachers ICT competence needs in ICT integration (hardware) based on the Technology Literacy approach of UNESCO ICT-CFT are high in the colleges of education.

Table 4: Student-teachers ICT Competence Needs in ICT Integration (Software)

\begin{tabular}{llr}
\hline S/N & Items & Mean \\
\hline 1 & Operating system & 2.66 \\
2 & Word Processing Application (e.g MS Word) & 2.66 \\
3 & Spread Sheet packages (e.g MS Excel) & 2.61 \\
4 & Graphical software (e.g CorelDraw) & 2.70 \\
5 & Presentation software (e.g power point) & 2.68 \\
6 & Design tools (e.g paint brush) & 2.51 \\
7 & Animation tools & 2.45 \\
8 & Web browsing (e.g internet explorer) & 2.63 \\
9 & Database Application & 2.68 \\
10 & Multimedia Applications & 2.57 \\
11 & Communication software e.g video conferences & 2.54 \\
12 & Electronic Learning Management System (EMLS) & 2.85 \\
& Grand Mean & $\mathbf{2 . 6 3}$ \\
\hline
\end{tabular}

Table 4 revealed a grand mean of 2.63 for student-teachers ICT competence needs in ICT integration (software) based on the Technology Literacy approach of UNESCO ICT-CFT. This reveals that student-teachers ICT competence needs in ICT integration (software) based on the Technology Literacy approach of UNESCO ICT-CFT are high in the colleges of education. 
Journal of Education and Practice

ISSN 2520-467X (Online)

Vol. 5, Issue No.1, pp 17 - 35, 2021

www.carijournals.org

Table 5: Student-teachers ICT competence Needs in ICT Integration (Competence needs in Using Hardware)

\begin{tabular}{llc}
\hline S/N & Items & Mean \\
\hline 1 & Desktop Computer & 2.34 \\
2 & Laptop Computers & 2.46 \\
3 & Palmtop Computers & 2.44 \\
4 & Wireless Internet & 2.36 \\
5 & Cable Internet & 2.44 \\
6 & Digital camera & 2.20 \\
7 & Scanner & 2.04 \\
8 & Video equipment & 2.22 \\
9 & Projector & 2.47 \\
10 & Educational software & 2.32 \\
11 & Television set & 1.84 \\
12 & Interactive boards & 2.10 \\
13 & Computer printer & 2.17 \\
14 & Photocopiers & 2.16 \\
15 & Virtual library & 2.27 \\
16 & Electronic bulletin board & 2.12 \\
17 & Electronic notice board & 2.18 \\
18 & Radio & 1.82 \\
19 & Tape recorder & 2.73 \\
20 & CD player & 2.76 \\
21 & Digital video disc player (DVD) & 1.85 \\
22 & Smart phones & 2.05 \\
23 & CD/DVD writers & 2.05 \\
& Grand Mean & $\mathbf{2 . 1 5}$ \\
\hline
\end{tabular}

Table 5 revealed a grand mean of 2.15 for student-teachers ICT competence needs in ICT integration (competency in using hard ware) based on the Technology Literacy approach of UNESCO ICT-CFT. This reveals that the ICT competence needs in ICT integration (competency in using hard ware) based on the Technology Literacy approach of UNESCO ICT-CFT high for the student-teachers in the colleges of education.

Table 6: Student-teachers ICT Competence Needs in ICT Integration (Competency in using software application)

\begin{tabular}{llc}
\hline S/N & Items & Mean \\
\hline 1 & Operating system & 2.44 \\
2 & Word Processing Application (e.g., MS Word) & 2.47 \\
3 & Spread Sheet packages (e.g., MS Excel) & 2.48 \\
4 & Graphical software (e.g., CorelDraw) & 2.47 \\
5 & Presentation software (e.g., power point) & 2.49 \\
6 & Design tools (e.g., paint brush) & 2.30 \\
7 & Animation tools & 2.19 \\
8 & Web browsing (e.g., internet explorer) & 2.23 \\
9 & Database Application & 2.37 \\
10 & Multimedia Applications & 2.29 \\
11 & Communication software e.g., video conferences & 2.27 \\
\hline
\end{tabular}


Journal of Education and Practice

ISSN 2520-467X (Online)

Vol. 5, Issue No.1, pp 17 - 35, 2021

WWW.carijournals.org

\begin{tabular}{lll}
\hline 12 & Electronic Learning Management System (EMLS) & 2.19 \\
Grand Mean & $\mathbf{2 . 3 5}$ \\
\hline
\end{tabular}

Table 6 revealed a grand mean of 2.35 for student-teachers ICT competence needs in ICT integration (competency in using software application) based on the Technology Literacy approach of UNESCO ICT-CFT. This reveals ICT competence needs in ICT integration (competency in using software application) based on the Technology Literacy approach of UNESCO ICT-CFT high for student-teachers in the colleges of education.

Table 7: Student-teachers ICT competence Needs in ICT Integration (Competency in Computer Operation)

\begin{tabular}{llc}
\hline S/N & Items & Mean \\
\hline 1 & Boot a computer & 2.09 \\
2 & Identify icon on desktop & 2.10 \\
3 & Select an application & 2.12 \\
4 & Run application & 2.13 \\
5 & Use the keyboard & 2.09 \\
6 & Use the mouse & 2.06 \\
7 & Search for a document & 2.03 \\
8 & Insert and access CD & 2.12 \\
9 & Save a document on CD/flash & 2.19 \\
10 & Connect the computer with other devices using cables & 2.16 \\
11 & Print a document & 2.07 \\
12 & Close an application & 2.04 \\
13 & Shut down the computer properly & 2.03 \\
& Grand Mean & $\mathbf{2 . 0 9}$ \\
\hline
\end{tabular}

Table 7 revealed a grand mean of 2.09 for student-teachers ICT competence needs in ICT integration (competency in computer operation) based on the Technology Literacy approach of UNESCO ICT-CFT. This reveals that the ICT competence needs in ICT integration (competency in computer operation) based on the Technology Literacy approach of UNESCO ICT-CFT is high for student-teachers in the colleges of education.

Table 8: Student-teachers ICT competence Needs in ICT Integration (Competency in Using Peripheral Devices)

\begin{tabular}{llc}
\hline S/N & Items & Mean \\
\hline 1 & Connect handset to the computer & 2.05 \\
2 & Connect the digital camera to the computer & 2.23 \\
3 & Use the interactive white board with the computer & 2.22 \\
4 & Use web cam to capture images & 2.14 \\
5 & Connect a multimedia projector to the computer & 2.37 \\
6 & Use a scanner to create and copy images & 2.26 \\
& Grand Mean & $\mathbf{2 . 2 1}$ \\
\hline
\end{tabular}

Table 8 revealed a grand mean of 2.21 for student-teachers ICT competence needs in ICT integration (competency in using peripheral devices) based on the Technology Literacy approach of UNESCO ICT-CFT. This reveals that ICT competence needs in ICT integration (competency in using peripheral devices) based on the Technology Literacy approach of UNESCO ICT-CFT is high for student-teachers in the colleges of education. 
Journal of Education and Practice

ISSN 2520-467X (Online)

Vol. 5, Issue No.1, pp 17 - 35, 2021

WWW.carijournals.org

Table 9: Student-teachers ICT Competence Needs in ICT Integration (Competency in Using Internet)

\begin{tabular}{llc}
\hline S/N & Items & Mean \\
\hline 1 & Surf the internet using a computer & 2.41 \\
2 & Surf the internet using a smart phone & 2.20 \\
3 & Use a search engine such as Google, devil finder etc. & 2.23 \\
4 & Make a web book mark & 2.08 \\
5 & Upload a file & 2.14 \\
6 & Download information on the computer & 2.05 \\
7 & Save downloaded information on computer & 2.01 \\
8 & Use images from a web page & 2.00 \\
9 & Modify an image or graphic with computer & 2.07 \\
10 & Participate in an online discussion or newsgroup & 2.19 \\
11 & Create and upload a webpage & 2.20 \\
12 & Send e-mail with an attachment & 2.27 \\
13 & Use information from web for a project or assignment & 2.09 \\
14 & Chat online using Facebook, yahoo messenger, WhatsApp, 2go, & 2.04 \\
& and so on & 2.10 \\
15 & Copy information from a download & 2.18 \\
16 & Paste copied information on a working page. & $\mathbf{2 . 1 4}$ \\
\hline
\end{tabular}

Table 9 revealed a grand mean of 2.14 for student-teachers ICT competence needs in ICT integration (competency in using internet) based on the Technology Literacy approach of UNESCO ICT-CFT. This reveals that ICT competence needs in ICT integration (competency in using internet) based on the Technology Literacy approach of UNESCO ICT-CFT is high for student-teachers in the colleges of education.

\section{Analysis of Hypotheses}

\section{Hypothesis one}

There is no significant difference between self-assessment of ICT competency needs by male and female student-teachers in the fourth level of UNESCO ICT-CFT on the technology literacy approach in colleges of education.

Table 10: Student-teachers ICT Competence Needs in ICT Integration Based on Gender

\begin{tabular}{lllcccc}
\hline Gender & N & Mean & SD & df & t & Sig (2tailed) \\
\hline Male & 491 & 316.22 & 31.13 & & & \\
Female & $\mathbf{7 2 0}$ & 307.04 & 41.73 & & & 0.00 \\
\hline
\end{tabular}

Table 10 shows the mean score of male and female student-teachers ICT competence needs in ICT integration. Male student-teachers $(\mathrm{M}=316.22, \mathrm{SD}=31.13)$ and the female studentteachers $(\mathrm{M}=307.04, \mathrm{SD} 41.73)$ are significantly different, $\mathrm{t}(1209)=4.15, \mathrm{p}=0.00$. Hence there was a significant difference among male and female student-teachers ICT competence needs in ICT integration based on the Technology Literacy approach of UNESCO ICT-CFT. This necessitated the rejection of the hypothesis. The difference is the direction of the male student-teachers. 
Journal of Education and Practice

ISSN 2520-467X (Online)

Vol. 5, Issue No.1, pp 17 - 35, 2021

www.carijournals.org

\section{Hypothesis two}

There are no significant differences in the area of specialization of student-teachers of selfassessment of ICT competency needs in the fourth level of UNESCO ICT-CFT on the technology literacy approach in colleges of education.

Table 11: Student-teachers ICT Competence Needs in ICT Integration Based on Area of Specialization

\begin{tabular}{llllllc}
\hline Items & N & Mean & Ranking & X2 & Df & Sig \\
\hline Education & 484 & 666.42 & 2 & & & \\
Sciences & 324 & 531.69 & 4 & & & \\
Vocation & 133 & 690.33 & 1 & & & \\
& & & & 44.05 & 4 & 0 \\
Languages & 126 & 607.31 & 3 & & & \\
$\begin{array}{l}\text { Arts and Social Sciences } \\
\text { Total }\end{array}$ & 144 & 415.63 & 5 & & & \\
\hline
\end{tabular}

A Kruskal-Wallis Test on table 11 revealed a statistically significant difference in optimism levels across five different area of specialization (Education, $n=484$, Sciences, $n=324$, Vocation, $n=133$, Languages, $n=126$ and Arts and Social Sciences, $n=144), \chi 2(4), n=1211$ ) $=44.05, \mathrm{p}=0.00$. This implies that there are significant differences in area of specialization of student-teachers ICT competence needs in ICT integration based on the Technology Literacy approach of UNESCO ICT-CFT.

\section{Summary of Findings}

a. ICT competence need in ICT integration (hardware and software) based on the fourth level of the Technology Literacy approaches of UNESCO ICT-CFT is high by student-teachers in the colleges of education.

b. There was a significant difference among male and female student-teachers ICT competence needs in ICT integration based on the fourth level of the Technology Literacy approach of UNESCO ICT-CFT.

c. There are significant differences in area of specialization of student-teachers ICT competence needs in ICT integration based on the fourth level of the Technology Literacy approach of UNESCO ICT-CFT.

\section{DISCUSSION, CONCLUSION AND RECOMMENDATIONS Discussion of Findings}

Finding arising from student-teacher ICT competence needs in ICT integration reveals studentteacher had high ICT competence needs in ICT facilities (hardware and software)'. This includes the use of ICT software and application packages. This finding is equally in line with UNESCO (2011) where it stated that student-teachers are expected to understand basic hardware and software applications that will enable their productivity in the day to day use of ICT. Titilayo (2010) study concur with this finding where it revealed that the number of ICT teachers who have basic technological skill in the use of ICT is low, In comparison Hooker, Mwiyeri and Verma (2011) reported that ICT technology domain such as the ability to use ICT open ended software packages appropriate to subject matter areas, the ability to use an authorizing environment or tools to design offline and/ or web resources is low. 
Journal of Education and Practice

ISSN 2520-467X (Online)

Vol. 5, Issue No.1, pp 17 - 35, 2021

WWW.carijournals.org

Finding from the study revealed that student-teachers gender had influence on student-teachers ICT competence needs in colleges of education in fourth level of UNESCO ICT-CFT in technology literacy approach. This difference is in the direction of male student-teachers. This finding agrees with the work of Schumacher and Moharan-Martin (2001) but at variance with that of Shapka and Ferrari (2003), Oyelaran-Oyeyinka and Adeya (2004) and Teck and Lai (2011) where they stressed the dominance female in ICT related activities. Also, it opposes Imhof, Vollmeyer and Beierlein (2007) and Bhattacharjee (2008) that reported that gender gap is shrinking or it no longer exist. Hence, the issue of gender and ICT remains inconclusive.

The findings revealed differences in the student-teacher area of specialization in the fourth level of UNESCO ICT-CFT in the technology literacy approach. This finding supported Oludipe (2004) that reported considerable differences in the computer literacy skills of teachers based on subject discipline; but this finding is at variance with the studies of Alcuin (2006), Thomas and Mart (2006), Olumorin (2008), Agbatogun (2010) and Daramola (2011) that reported no differences on the influence of area of specialization of student-teachers on competence, literacy level and use of ICT. This indicates that more studies need to be conducted in this area in view of variations.

The findings on student-teachers ICT competence needs indicated that they have high need of ICT competence in the technology literacy approach of the fourth level of UNESCO ICT-CFT. This implied that student-teachers are aware of the benefit inherent in the use of ICT in their professional practice. However, considering the policy on integration of ICT into the teaching learning process in Nigerian school system, the current high level of ICT competence needs by student-teachers is still worrisome. Gender differences in student-teachers ICT competence needs based on the technology literacy approach of the fourth level of UNESCO ICT-CFT, calls for concern while planning and procuring ICT for student-teacher. This is very important of the girl child in to benefit maximally from the current drive to integrate ICT into educational practice in Nigeria. Similarly, the differences in student-teachers area of specialization in their ICT competence needs in the technology literacy approach of the fourth level of UNESCO ICT-CFT equally implied that attention should be given to student-teachers' area of specialization while panning for the integration of ICT into teaching and learning in colleges of education since the use of ICT cut across all discipline.

\section{Conclusion}

Few researches available used various ways to investigate educational needs. This present study was not different as it adapted the UNESCO ICT-CFT to investigate self-assessment of ICT competence needs among student-teachers in colleges of education. UNESCO ICT-CFT was modified to suit the purpose and context in which the study was conducted. The present study discovered that student-teachers have high ICT competence needs in colleges of education based on the technology literacy approach of the fourth level of UNESCO ICT-CFT. The study reveals significant differences in the student-teachers ICT competence needs based on gender and the difference was in the directions of the male student-teachers. Similarly, area of specialization had significant differences too. As colleges of education are under pressure to use ICT to provide future teachers with the necessary knowledge and skills to prepare them for the $21^{\text {st }}$ century, adequate teacher professionalization becomes a prerequisite to transform education in such a way that teachers have the technological and pedagogical knowledge and skills to use ICT to cater for student individual preferences. As a result, colleges of education should prepare student-teachers on the use of ICT facilities in their chosen career bases on their identified needs. 
Journal of Education and Practice

ISSN 2520-467X (Online)

Vol. 5, Issue No.1, pp 17 - 35, 2021

WWW.carijournals.org

Based on the finding of the study, conclusions can be that UNESCO ICT-CFT has built support for government private sectors to create content, execute frameworks and measurement of teacher competencies, as part of a comprehensive approach to education reform. In order for teachers to include ICT in their daily practices, there is need to assess the ICT competence needs of student-teachers who are teachers in training and they must have confidence when using these new educational resources during their training.

\section{Recommendations}

Based on the findings of this study, discussions and conclusions drawn from it, the following recommendations were made

i. Government in collaboration with private sector should provide student-teachers with the required ICT needs to be at par with their counterpart from other parts of the world

ii. Government and authorities of colleges of education should take into consideration female student-teachers while planning to integrate ICT in colleges of education and in procurement of ICT facilities.

iii. Also, student-teachers area of specialization should be taken into consideration during the purchase of ICT facilities for student-teachers use in colleges of education.

\section{REFERENCES}

Agbatogun A. O. (2010). Gender, academic qualification and subject discipline differentials of Nigerian Teachers' ICT literacy. Journal of Academic Leadership. Retrieved from http://www.academicleadership.org/emprical_research.

Albirini, A. (2006). Teachers' attitudes towards Information and Communication Technologies: the case of Syrian EFL teachers. Computers and Education, 47(4), 373398.

Archibong, I. A. A., Ogdiji, J. E. \& Anijaobi-Idem, F. (2010). ICT competencies among Academic staff in Universities in Cross River State, Nigeria, Computers and Information Science, 3(4), 109-115.

Bandele S. O. (2006). Development of modern ICT and internet system. In A. A. Agagu (ed). Information and communication technology and computer Applications. Abuja: Panof Press. $1-3$.

Bello, S. (2006). Managing Educational Cost. Lagos: Tanimowo Resources Limited.

Bhattacharjee, B. (2008). Factors affecting computer use among older adult users: a study in the backdrop of the Florida State University. Ph.D dissertation. Retrieved from http://etd.lib.fsu.edu/theses/available/etd-01032008-153043/unrestricted/Bo nnie.pdf

Daramola, F. O. (2011). Information and Communication Technology Literacy Levels among Student-Teacher in selected states in North Central, Nigeria. Doctoral Dissertation. Department of Science of Education, University of Ilorin.

Hooker, M., Mwiyeria E. \& Verma, A. (2011). ICT Competency Framework for Teachers in Tanzania. Teacher Development for the 21st Century (TDV21) Pilot. A Ministry of Education and Vocational Education Tanzania, World Bank And GESCI Initiative. 
Journal of Education and Practice

ISSN 2520-467X (Online)

Vol. 5, Issue No.1, pp 17 - 35, 2021

WWW.carijournals.org

Imhof, M., Vollmeyer, R. \& Beierlein C. (2007). Computer use and the gender gap: The issue of access, use, motivation, and performance. Computers in Human Behavior, 23, 2823 2837.

Johnson, N. (2012).Availability and Use of ICT among Teacher Educators in Karaikal Region. International Journal of Educational Research and Technology, 3(1), 37-39. Retrieved from www.soeagra.com/ijert.htm

Lim, C. P. (2012). Editorial 28(6): Preface to the Special issue. In C. P. Lim \& C. S. Chai (Eds), Building the ICT capacity of the next generation of teachers in Asia. Australasian Journal of Educational Technology, 28(Special issue, 6), iii-xv. Retrieved from http://www.ascilite.org.au/ajet/ajet28/editorial28-6.html

Lim, C. P. \& Chai, C. S. (2008). Rethinking classroom-oriented instructional development models to mediate instructional planning in technology-enhanced learning environments. Teaching and Teacher Education, 24(8), 2002-2013. http://dx.doi.org/10.1016/j.tate.2008.05.004

Markauskaite, L. (2006). Gender issues in per service teachers' training: Information and Communication Technology literacy and online learning. Australasian Journal of Educational Technology. 22(1), 1-20.

Markauskaite, L. (2007). Exploring the structure of trainee teachers' ICT literacy: the main components of, and relationships between, general cognitive and technical capabilities. Educational Technology, Research and Development, 55(6), 547.

Miller, O. \& Akume, B. S. (2009).The challenges of effective application of ICT aided learning in office technology education. A paper presented at the $21^{\text {st }}$ annual national conference of association of business educators of Nigeria (ABEN) on the $13^{\text {th }}-17^{\text {th }}$ October, 2009 at Abia State Polytechnic Aba, Abia State.

Nash, J. (2009). Computer skills of first-year students at a South African university. Proceedings of the 2009 Annual Conference of the Southern African Computer Lecturers' Association, Eastern Cape, South Africa (SACLA '09), Mpekweni Beach Resort, South Africa, June 29-July 01, 2009.

National Commission for Colleges of Education. (2012). Minimum Standards for Nigeria Certificate in Education. (2012 Edition). Abuja: NCCE.

Ojedokun, A. A. \& Owolabi, E.O. (2003). Internet access, competence and the use of the internet for teaching and research activities by University of Botswana academic staff. African Journal of library, Archives and Information Science, 13 (1), 43-54.

Ololube, N. P. (2006). Teachers Instructional Material Utilization Competencies in Secondary Schools in Sub-Saharan Africa: Professional and non-professional teachers' perspective. In Conference Proceedings of the 6th International Educational Technology Conference EMU, 19-21 April 2006 North Cyprus.

Olumorin, C. O. (2008). Tertiary Institutions Lecturers Attitudes to, Competence in and Use of Computer in Kwara State. Nigeria. Doctoral Dissertation. Department of Science of Education, University of Ilorin. 
Journal of Education and Practice

ISSN 2520-467X (Online)

Vol. 5, Issue No.1, pp 17 - 35, 2021

WWW.carijournals.org

Omoniyi, T. \& Quadri, A.T. (2013). Perceived competence of Nigerian Secondary School teachers in the use of Information and Communication Technology (ICT). Journal of Education and Practice, 4(10), 157-164.

Oyediran O. S. \& Odusami, K. T. (2004). Whither the Nigerian Quantity Surveyors in the

Information Technology Age. An International Journal of Information and Communication Technology (ICT). 1 (1 \& 2) 1-16.

Oyelaran-Oyeyinka, B \& Adeya, J. O. (2004). Challenges of ICT in Nigeria. Journal of Elearning, 8(1). 25-38.

Schumacher, P. \& Moharan-Martin, T. (2001). Gender, Internet and computer experiences. Computer in Human Behavior, 17, 95-110.

Shapka, J. D., \& Ferrari, M. (2003). Computer related attitudes and actions teacher candidate. Computers in Human Behaviour, 19(3), 319-334.

Sharma, A., Lanum, M., \& Suarez-Balcazar, Y. (2008). A community needs assessment guide, Loyola, University of Chicago. Retrieved from http://www. luc.edu/curl/pdfs/acommunityneedsassessmentguide.pdf

Shukre S. (2008). The Future of Online Education in India. In A. Varma (Ed), Information and Communication Technology in Education. First edition. Hyderabad: ICFAI University Press Society for Information Technology and Teacher Education (2002). SITE position paper:

statement of basic principles and suggested actions (Ames White Paper). Retrieved from www.aace.org/site/SITEstatement.htm

Tayo, O. \& Adedayo, T. Q. (2013). Perceived Competence of Nigerian Secondary Schools

Teachers in the Use of Information and Communication Technology (ICT). Journal of Education and Practice, 4(10), 157-164. Retrieved from www.iiste.org

Tezci, E. (2009). Teachers' effect on ICT use in education: The Turkey sample. Procedia Social and Behavioral Sciences. 1, 1285-94.

Thomas, M. L. \& Marz, R. (2006). Computer literacy and attitudes towards e-learning among first year medical students. Retrieved from http://www.biomedical.con/1472_6920/6/3

Tinio, V. (2004). ICT in education: an e-premier. UNDP: Kuala Lumpur

Titilayo, A. E. M. (2010), Realities of Integrating Information and Communication

Technology in Nigeria Secondary Schools. (Experience from a Local Government in Osun State, Nigeria), Journal of Africa Society for Scientific Research, 1(3), 654 - 660.

UNESCO (2005). Regional Guidelines on Teacher Development for Pedagogy- Technology

Integration (Working Draft). Thailand: UNESCO Asia and Pacific Regional Bureau for Education. (Electronic Version). Retrieved from www.unesdoc.unesco.org/images/0014/001405/140577e.pdf

UNESCO (2008). UNESCO ICT Competency Framework for teachers'version 1 .0. Paris: UNESCO 
Journal of Education and Practice

ISSN 2520-467X (Online)

Vol. 5, Issue No.1, pp 17 - 35, 2021

www.carijournals.org

UNESCO (2011). UNESCO ICT Competency Framework for teachers' version 2.0. Paris: UNESCO

UNESCO (2018). UNESCO ICT Competency Framework for teachers' version 3.0. Paris: UNESCO

Yildirim, S., Kynigos, C., Potolea, D., Dumont, B., \& Aufenanger, S. (2003). Teacher training and the role of teachers in the communication society. Learning and teaching in the communication society. Strasbourg: Council of Europe Publishing.

Yusuf, M. O. (2005). An investigation into teachers' self-efficacy in the implementation of computer education in Nigerian Secondary Schools. Meridian: A Middle School Computer Technologies Journal, 8 (2). Retrieved from http://www.ncsu.edu/meridian/sum2005/index.html.

Yusuf, M. O. \& Balogun M. R. (2011). Student-teachers' competence and attitude towards information and communication technology: a case study in a Nigerian University. Contemporary Educational Technology, 2(1), 18-36. Retrieved from http://www.cedtech.net/articles/21/212.pdf 